\title{
Editorial
}

\section{Optimizing Co-parenting to Develop Entrepreneurial Personality in Children}

\author{
Jenny Lukito Setiawan \\ School of Psychology \\ Universitas Ciputra Surabaya
}

\begin{abstract}
Over the course of her career as a psychologist, the writer has encountered a lot of problems in children, which when being explored further on, turned out to originate from problems related to parenting and marriage. On the other hand, throughout the years of being a lecturer, the writer has become convinced that it is essential for Indonesia's young generation to have entrepreneurial personality characteristics in order to improve the nation's competitiveness. Her experience as a psychologist and her journey as a lecturer have inspired the writer to explore marital and parenting problems, and how both of them can be worked on to facilitate the development of entrepreneurial personality characteristics in children, for the sake of nation's advancement.
\end{abstract}

Keywords: co-parenting, entrepreneurial personality, entrepreneurial characteristics, marriage

Dalam perjalanan sebagai psikolog, penulis menemui banyak permasalahan anak, yang ternyata ketika ditelusuri lebih jauh, berawal dari permasalahan terkait dengan parenting dan pernikahan orang tua. Di sisi lain, dalam perjalanan sebagai dosen, penulis disadarkan dan menjadi semakin yakin bahwa generasi muda bangsa Indonesia perlu sekali memiliki karakter entrepreneurial karena hal ini menjadi dasar untuk meningkatkan daya saing bangsa. Pengalaman sebagai psikolog dan perjalanan sebagai dosen member inspirasi untuk mendalami lebih jauh masalah pernikahan dan parenting, serta bagaimana kedua hal ini dapat diupayakan untuk memfasilitasi perkembangan karakter entrepreneurial anak, demi kemajuan bangsa.

Kata kunci: co-parenting, kepribadian entrepreneurial, karakter entrepreneurial, pernikahan

It is very encouraging to see that entrepreneurship movements have begun to start happening in Indonesia since a few years ago. Entrepreneurship movements are carried out on the basis of a belief that entrepreneurship is the answer or solution to end poverty and bring prosperity to the nation. Entrepreneurship movements are evident in the great amount of educational institutions concerned with entrepreneurship education. Most educational institutions include entrepreneurship education through optional extracurricular activities, while some institutions incorporate entrepreneurship education into the mandatory curriculum for students.

A rewrite of the Inaugural speech as Professor of Counselling Psychology

Correspondence concerning this article should be addressed to Jenny Lukito Setiawan, School of Psychology Universitas Ciputra, UC Town, CitraLand, Surabaya 60219. Email: jennysetiawan@yahoo.com
The awareness of the importance of entrepreneurship education is evident in various programs launched by the government, such as Student Entrepreneurship Program (Program Mahasiswa Wirausaha) organized by Directorate General of Education and Student Affairs, Ministry of Research, Technology, and Higher Education of the Republic of Indonesia. This program aims to change students' mindset to become job creators and encourage entrepreneurship units in higher education institutions to support entrepreneurial programs. Another program with a similar mission is Indonesian Student Entrepreneurship Expo (Expo Kewirausahaan Mahasiswa Indonesia - EKMI) held by the Directorate General of Education and Student Affairs. EKMI aims to increase the number of student entrepreneurs.

Without trying to play down the meaning of the 
entrepreneurship movements, entrepreneurship education should not stop only at the development of business skills. Katz (2007) argued that psychological processes are very important to the process of entrepreneurship. In her review of Katz' argument, Chell (2008) maintained that entrepreneurship education has to extend beyond business planning, financial, and management training. Entrepreneurship education should be able to help students to realize their creative potential and stimulate a desire to develop their entrepreneurial abilities.

Psychological aspects of entrepreneurship raised by Katz (Chell, 2008) are certainly inseperable from the individual or figure behind the entrepreneurial works. Furthermore, it is related to the entrepreneurial characteristics or psychological characteristics possessed by the individual. This is a challenge as well as a call for psychology scientists to conduct further research on personality characteristics of an entrepreneur and psychological variables related to the infrastructure of an entrepreneur's environment (Hisrich, Langan-Fox, \& Grant, 2007).

When talking about personality characteristics of an entrepreneur or entrepreneurial personality, there are various social agents that actually have a role and responsibility in shaping them in children, such as family, educational institutions, and the community (Setiawan, 2008). However, it is not uncommon for educational institutions to face challenges from families when they conduct efforts to develop entrepreneurial characteristics. In fact, parents, as the first and foremost social environment in developing the child's personality, are not ready with the challenges given by the educational institution to their child.

This oration aims to describe the role of family, especially parents, in developing entrepreneurial personality through co-parenting. Specifically, this oration will analyze three important parts, namely entrepreneurial personality and the development in children, co-parenting efforts that can be done to facilitate the growth of entrepreneurial personality in children, and also efforts to optimize co-parenting.

\section{Entrepreneurial Personality and Efforts to Develop}

According to Hisrich, Peters, and Shepherd (2005), entrepreneurship is a process of creating something new and valuable by devoting time and effort, calculating financial, psychological, and social risks, in order to earn an achievement, either monetary rewards, personal satisfaction, or independence. In line with this, Bolton and Thompson (2004: 16) argued that an entrepreneur is "a person who habitually creates and innovates to build something of recognized value around perceived opportunities." There are at least two reasons why their descriptions are interesting to be analyzed. First, they emphasized that entrepreneurship is a habit to create and innovate, not an urge to innovate that appears occasionally. Second, the output of the innovative process is to produce value that is not always in the form of money, but also something socially or aesthetically valuable (Setiawan, 2008).

Various studies have been conducted to examine psychological characteristics of an entrepreneur or entrepreneurial personality. Rauch and Frese (2007) summarized various entrepreneurial personality characteristics into six characteristics, including a high need for achievement, having courage to take risk, innovativeness, autonomy, internal locus of control, and high self-efficacy. Individuals with high achievement motivation seek to achieve high quality work and persevere in efforts made to achieve their goals (Setiawan, 2011). They usually prefer challenging tasks at an intermediate level, rather than routine or very difficult tasks. Individuals with high achievement motivation take responsibility for their work performance and strive to improve it. For that reason, they seek feedback on their performance.

Courage to take risks is defined as a tendency to take risks. Individuals with high achievement motivation will take risks at a moderate level. In other words, courage to take risks is the courage to take calculated risks (calculated risk-taking). Innovativeness refers to the willingness and interest to find new ways to act (Rauch \& Frese, 2007).

Autonomy refers to the independence in setting goals, developing action plans, as well as controlling the accomplishment of goals. Autonomous individuals tend to reject rigid restrictions that limit their movement. Individuals with an internal locus of control perceive that they themselves have control of things that happen in their life. This pushes them to actively change a situation. On the contrary, individuals with an external locus of control will believe that they are controlled by other people or events outside of themselves, making them passive and submissive (Rauch \& Frese, 2007).

Self-efficacy is related to the self-confidence in doing a certain task or action effectively. Individuals who have high self-efficacy are more persistent in striving when problems or obstacles come up and seek to take action to fix it (Bandura, 1997). 
Entrepreneurial personality characteristics should not only be possessed by those who aspire to start a business, but also the next generation of the nation. As stated by Ciputra, the father of entrepreneurship in Indonesia, an entrepreneur is not only related to the business world (business entrepreneur), but also other fields (such as government entrepreneur, social entrepreneur, academic entrepreneur). With entrepreneurial characteristics, Indonesia's performance in areas of health, education, economic environment, techonology, and other areas - which are the pillars of nation competitiveness - will increase. This will become the basis to drive Indonesia's economic growth (World Economic Forum, 2016).

\section{Determinants of Personality Development in Children}

The debate over the factor that determines the personality development in children, whether it is hereditary or environmental, will never end. The fact that hereditary factors or genetic aspects contribute to the development of a certain personality characteristic in a child cannot be denied. However, focusing on genetic factors or heredity alone seems to obstruct things that still can be done throughout the child's development. In various studies, psychology scientists have found that environmental factors hold a very important role in an individual's personality and character development (i.e. Bandura in Social Learning Theory, Erikson in Psychosocial Development).

The importance of environmental factors was reconfirmed in the Ecological Theory developed by Urie Bronfenbrenner. In his theory, Bronfenbrenner asserted that a child's development reflects the influence of various environmental systems. There are five environmental systems identified by the theory, namely microsystem, mesosystem, exosystem, macrosystem, and chronosystem (Santrock, 2015).

Microsystem is related to the setting where the individual lives. The relevant context in this case is family, friends, and school. Since microsystem is the innermost system, direct interaction between the individual and important social agents, such as family, parents, peers, and teachers, happen in this system.

Mesosystem is the relations between microsystems or inter-context relations. For example, experiences obtained by the individual from the family can influence their behavior when interacting with teachers and friends.

Exosystem links the wider social setting with the individual context. For example, the parents' job and regulations of the company where they work is not an environment that directly influences the child, yet they still affect the child's development. Company regulations will influence the family life and the parents' mindset and behavior in parenting.

Macrosystem is the culture where the individual lives, which involves behavior patterns and beliefs handed down from generation to generation. Chronosystem involves life events which lead to transitions in life, for example, parents' divorce or parents' business bankruptcy. The five systems influencing child's development can be seen at Figure of Bronfenbrenner's Ecological Theory of Development (Santrock, 2015: 26).

According to Janis (1969), from all social agents, parents have the greatest influence on child development, followed by siblings, peers, teachers, and social media. The hierarchy of influence of various social agents follows a chronological order in achieving its maximum effect. Janis argued that parents and siblings have the greatest influence, especially during the first six years of a child's life. Peers and teachers have a great influence during the pre-adolescence period, while social media has a great influence, particularly during adolescence. It does not mean that after the first six years of life, parents do not have an influence on a child's personality development, however the influence of other social agents, such as teachers, peers, and social media have become stronger in the subsequent developmental years.

\section{Family as an Important Environment for Personality Development in Children}

The family environment where the individual is raised leaves a great influence on the individual's personality development. Family provides the primary and most important influence in a child's personality development. Father and mother have a very critical and significant role in the child's identity development stage (Küçük, Habaci, Göktürk, Ürker, \& Adiguzelli, 2012). This is because family, especially father and mother hold an important role in the early stage of personality development. The foundations of personality in the individual's early years of life emerge in personal characteristics that form their behavior as adults.

Parental influence in a child's personality development and behavior formation is manisfested in several ways, namely through reward, punishment, instruction, and modelling (Janis, 1969). The four mechanisms are present in the parents' role as a cha- 
racter builder, character enabler, and character engineer (Hartini, 2011). The mechanisms of reward, punishment, and instruction are present in two aspects of parenting, which are parental support and parental control (Pudjibudojo, 2011), and also two dimensions of parenting, which are dimension of acceptance and responsiveness, and dimension of demand and control (Santrock, 2015).

Based on the dimensions developed by Baumrind and expanded by Maccoby \& Martin-dimension of acceptance and responsiveness and also dimension of demand and control-there are four styles of parenting, namely authoritarian, authoritative, indulgent, and neglectful (Santrock, 2015). In authoritarian parenting style, parents impose limits and strict control, but do not make efforts to fulfill the wishes and needs of the child. This will make the child unhappy, filled with fear and anxiety. The child will become afraid to take initiatives and lack good communication skills. This parenting style inhibits the growth of social skills in children (Santrock, 2015).

In authoritative parenting style, parents encourage the child to be independent, but still set limits and control towards the child's behavior. On the other hand, parents are also sensitive and responsive towards the needs of the child. This parenting style fosters the growth of social skills in children. Children whose parents implement authoritative parenting style have better self-control, and are more confident and achievement-oriented. They are also more capable of establishing good relationships with peers, working with adults, and coping with stress (Santrock, 2015).

In indulgent parenting style, parents are very involved and strive to be responsive towards the child's needs and demands, but do not give demands and control to the child. This parenting style is associated with poor self-control in children, because they never learn to adjust themselves with the demands and expectations of others. As a result, children from this parenting style grow to be egocentric individuals who like to dominate. They also may run into relationship problems with peers (Santrock, 2015).

In neglectful parenting style, parents are not involved in the child's life. They neither meet the child's wishes and needs, nor give demands and control towards the child's behavior. In other words, the child is considered non-existent. Such abandonment causes the child to develop a poor and immature selfesteem. During adolescence, it is not uncommon for children of this parenting style to develop aggressive behavior as an expression of dissatisfaction and emp- tiness that they feel in life (Santrock, 2015).

In relation to entrepreneurial characteristics, various literature support the notion that entrepreneurial personality characteristics are not innate or accidental, but rather are determined by the conditions of the environment (Bolton \& Thompson, 2004; Chell, 2008; Morris, 1998). Thus the mechanisms of character and behavior development in a child, that consist of reward, punishment, instruction, and modelling, which are the elements in parent-child relationship, also applies to the development of entrepreneurial personality. When linked with the development of entrepreneurial personality, namely high achievement-motivation, autonomy, internal locus of control, and high self-efficacy, authoritative parenting style is more likely to develop entrepreneurial personality.

Aside from reward, punishment, and instruction, entrepreneurial personal characteristics also develop from vicarious learning or role modelling (Chell, 2008). In role modelling, a child observes and models his or her parents (Scherer \& Adams, 1989). This mechanism is often not realized by parents, but has a strong influence. Given that parents are the individual's first and primary environment, they serve as a model of entrepreneurial personality development in children. Thus, if parents expect their child to have entrepreneurial characteristics, such as high need for achievement, having courage to take risks, innovativeness, autonony, internal locus of control, and high selfefficacy, then the characteristics should be evident in their own behavior.

\section{Co-parenting}

\section{Definition and Components of Co-parenting}

Parenting is a commonly used term, which generally means efforts to be a parent, or child-rearing efforts. In efforts to be a parent, there are daily tasks to care for and educate the child. Included are parents' activities in interacting with the child, provision of rules, giving rewards, or punishments.

Most people still believe that parenting is the mother's duty, because the father has already taken the role as the breadwinner and provide for the family. Often, this causes parents to seemingly have an unwritten agreement that father and mother have clearly different and unexchangeable roles. This is apparent in the higher amount of literatures discussing the role and involvement of mothers than literatures related to the involvement of fathers in parenting. 
Since that the child's personality is the result of interaction of parents with their children and the child's imitation and observation of the closest people to him/her, both father and mother, have a role in developing the child's personality, whether they realize it or not, deliberately or not.

The term co-parenting is usually used in literatures related to divorce, which means the negotiation between father and mother when they get a divorce, regarding child-rearing matters (example: Maccoby, Depner, \& Mnookin, 1990). James McHale, one of the pioneers of the study of co-parenting defines co-parenting as an effort done by two or more adults who care for and raise children who are their shared responsibility (McHale, \& Lindahl, 2011). Co-parenting occurs when such individuals have a shared or overlapping responsibility in raising a child, which contains support or coordination (Feinberg, 2003). In this case, members of the extended family, divorced or adoptive parents, or other caregivers can act as coparents.

Raising a child is inseparable from coordination and collaboration between father and mother or husband and wife. In this oration, the term co-parenting used refers to the coordination between the father and mother in nurturing and raising the child. In the context of marriage, co-parenting is a part of husbandwife coordination in their shared responsibility of nurturing and raising children (Cordova, 2009). K. D. Pruett and Pruett (2009) used the term partnership parenting to explain co-parenting. Partnership parenting is a team approach in conducting parenting, so that both father and mother take an active role and work together in child-rearing.

In co-parenting, a component familiar to parents is the division of parenting tasks. A very rigid division of tasks to do this and that, such as who teaches the child, who takes and picks up the child from school, and who buys the child's needs, are not uncommon.

Co-parenting should not only be viewed as a division of daily tasks in parenting. The concept of co-parenting is actually a joint activity between father and mother in raising children (McHale, KuerstenHogan, \& Rao, 2004). Besides the division of daily tasks, there are other important components of coparenting. In the summary of McHale's views, Cordova (2009) mentioned sense of we-ness, feelings towards partner, and active involvement of every team member (i.e. father/husband and mother/wife) in parenting as the important components in the co-parenting alliance between husband and wife.

Sense of we-ness is the extent to which the father and mother feel that the parenting efforts they do is a part of a joint effort as a team. When the father and mother have a sense of we-ness, they will not jealousy count and compare their tasks in doing their role as a parent. They will also not consider that they deserve more credit than their partner, because they think that what they do is a part of a joint effort as a team.

In other words, this sense of we-ness is a manifestation of solidarity and mutual support with the partner. In the context of educating the child to be able to develop entrepreneurial personality characteristics, a sense of we-ness between husband and wife is needed. When one parent trains his/her child to be independent and autonomous, not easily satisfied, persistent, strive to achieve results as best as possible, and taking risks, it is done as a part of an agreement or goal that the husband and wife have designed for their children.

Another component in co-parenting is related with feelings towards partner. In the reality of everyday parenting, it is not uncommon to find that what the husband does in his role as a parent do not fit the wife's thoughts and expectations, and vice versa. On a more extreme side, there are times when the husband or the wife does parenting efforts that are contrary to what the partner does. Such things can cause the husband or the wife to experience negative feelings towards their partner in their role as a parent. On the other side, if the husband/wife does things in accordance with what their partner thinks, support their partner's decision and parenting efforts, then the partner will have more positive feelings. The presence of positive feelings towards the partner in their role as a parent is one of components of good coparenting.

The next component is concerning the involvement of each team member (husband/wife) in parenting. Both husband and wife are engaged in the lives of their child. Both of them actively direct the child to a positive direction.

From the definition and components of co-parenting, it appears that in order to establish co-parenting, active participation of the father and mother is needed. Cordova (2009) stated that co-parenting becomes a challenge when there is an established system in the family that every matter related to the child is the mother's problem, or when one of the parents feels greater and more expert in parenting. This will inhibit their partner to engage any further.

It is even harder when the father and mother have different parenting philosophies (Cordova, 2009), for example, the father emphasizes the important of 
independence in the child, while the mother feels that parents have a responsibility to always help and assist the child in every difficulty. Covert competition between the father and the mother to gain respect and acceptance from the child is also an inhibiting factor in establishing good co-parenting. In fact, it is not uncommon for child-rearing disagreements to appear in front of the child, thus negatively impacts the child (O'Leary \& Vidair, 2005).

\section{Reasons for Co-parenting}

The father's involvement in parenting is very important for a child's development. Fathers' involvement will produce a socially and emotionally healthy child. The involvement also produces stronger cognitive and academic abilities, and also a more stable personality in child (K. D. Pruett \& Pruett, 2009).

According to K. D. Pruett and Pruett (2009), the nature and quality of the father-mother relationship in parenting has a great influence on the child's development, either positively or negatively. If co-parenting is done well, then the child will also develop well. On the contrary, if the co-parenting is not done well, then it will have a negative impact on the child's development. This was confirmed by the results of a study conducted by Marsha Pruett (K. D. Pruett \& Pruett, 2009), which showed that parental (fathermother) relationship forms the basis of all relationships in the family. When the parental relationship is weak and poor, other relationships in the family also become poor, causing the children to suffer and experience problems.

In their argument, K. D. Pruett and Pruett (2009) stated that family is an entity that is greater than the sum of parts (mother-child, father-child, or husbandwife). The system of relations between the smaller parts in the family will form a dynamic and determine the way each family member adapts with family life day by day. Therefore, it is not surprising that Cordova (2009) also stated that good co-parenting alliance will make parenting become more effective. Instead, poor co-parenting alliance will make parenting become ineffective, although perhaps each parent is competent in parenting.

In line with this, a study conducted by Kurniawan \& Setiawan (2016) also found that co-parenting is a predictor of parental support given in order to enhance entrepreneurial characteristics in the child. The more the co-parenting is perceived as satisfying, the more the individual will be capable in providing support to the child, whether in the form of emotional support or instrumental support in order to enhance entrepreneurial characteristics in the child.

\section{Co-parenting Focused on Entrepreneurial Personality Development}

There are several important things that need to be pursued in order to create co-parenting that focused on entrepreneurial personality development. First, father and mother should build a consensus on the goal they want to achieve in parenting. In other words, father and mother need to devise a shared vision as a goal they want to achieve in educating their child. It is essential that the father and mother take some time to discuss about personality characteristics they want to build or grow in their child. As for co-parenting that focuses on building entrepreneurial personality characteristics in the child, both father and mother need to share a common view that the characteristics are indeed good and have to be developed in their children. This agreement is very important because it will become the basis of implementing co-parenting in order to build entrepreneurial personality in the child. If the father and the mother do not share a common view, then the parenting will be ineffective, because they will undermine each other and impede the achievement of objectives.

Second, both father and mother should build togetherness as a team as an effort to conduct authoritative parenting. The struggle between the two ends of the dimension of acceptance and responsiveness, and both ends of the dimension of demand and control in parenting practices is tough to be solved. It is not uncommon for parents who intend to instill the spirit to achieve by encouraging the child to accomplish maximum achievement go overboard by giving demands regardless of the child's abilities. The attitude of parents when children encounter difficulties, whether they encourage the child to keep trying or accept the child when he/she gives up when facing difficulties; whether they encourage the child to take greater risks or encourage the child to take the choice which has an obvious success rate; whether they allow the child to seek the solution of his/her problem on her/her own or help the child in facing the problem; is not easy to be determined.

To find the balance between the two ends of the dimensions, parents need to take a look back at the child's age, abilities, condition, and efforts he/she has done. This is where parenting becomes very 
dynamic. The situation becomes even difficult when husband and wife do not have the same mindset. Child rearing disagreements often result in inconsistent treatment between the father and mother. It is not uncommon for the mother to be too "affectionate" and protective of the child, while the father gives great challenges and demands to the child. The mother tries to keep the child from experiencing failures, making efforts in order to keep the child away from difficulties, under the pretext of 'pity.' On the contrary, the father is less tolerant of the child's condition. Disagreements within this step impede the co-parenting efforts to develop entrepreneurial personality characteristics in the child. For this reason, togetherness as a team, communication between father and mother as team members, will allow both of them to discuss, share their own views, and give corrections to their partner, and act as a control.

Third, the father and mother should work as a team in building a healthy self-esteem in their child. Setiawan (2005) stated that children who have healthy self-esteem will view themselves in a positive way and feel that he/she is important. The child will be able to accept him/herself. Consequently, the child will be more capable in actualizing the abilities and potentials he/she has. They will be proud and happy when they make the best of themselves. In contrast, children who have poor self-esteem are very sensitive to criticisms and work hard to gain acceptance and avoid rejection (Owens, 1995). In other words, a child that has healthy self-esteem will have a more solid foundation that encourages him/her to excel as an actualization of the abilities he/she has (Nwankwo, Obi, \& Agu, 2013). They will have greater courage to try something new or to innovate, are more confident to be persistent, and not to give up (Di Paula \& Campbell, 2002). Healthy self-esteem will also enable the child to develop internal locus of control (Saadat, Ghasemzadeh, Karami, \& Soleiman, 2012). This will support the development of entrepreneurial personality characteristics.

Fourth, couples that acts as a father and a mother need to build and remind each other to become role model for their child in regard to entrepreneurial personality characteristics. Parents need to be aware that they serve as an example that has a greater influence than the instructions they give to their child. Parents should also demonstrate attitudes and behaviors that show their efforts in achieving the best possible results, risk-taking, courage in trying something new, having persistence, and do not surrender to any circumstances.

\section{Strengthening Marital Relationships as a Pillar of Co-parenting}

As explained earlier, co-parenting is the coordination between father and mother in nurturing and raising their child. Good co-parenting is absolutely not something that can be achieved immediately. The father and the mother grew up in different families, which have different parenting styles, philosophies and beliefs. Views on which values are priorities in life, the most important things the child has to achieve, and how to achieve it, can not be separated from the family and cultural context where the individual was raised. This often creates a conflict in parenting causing co-parenting to be ineffective.

A study conducted by Morrill, Hines, Mahmood, and Cordova (2010) showed that the quality of good marital relationships affects positive co-parenting alliance, which in turn affects the father or the mother's practice of parenting. When the father and the mother have a good marital quality, they will have a higher level of satisfaction towards their partner, able to enjoy the togetherness, and have a good emotional connection. It enables them to collaborate and support each other in their efforts to deal with their children, both personally and as a team.

When the father and the mother are able to coordinate and support each other, they will be able to respond empathetically to the child's needs and spend time positively with the child, and also become more sensitive to their child's needs. On the contrary, if the father and the mother have a poor relationship, filled with tension, conflict, and hatred, they will experience difficulties in showing support towards each other in their parenting efforts. In such circumstances, the child will also experience a negative effect or even become an object of his/her father and mother's annoyance and dissatisfaction.

A study conducted by Christopher, Umemura, Mann, Jacobvitz, and Hazen (2015) also confirmed that the parents' marital quality in their transition to parenthood is a predictor of co-parenting quality and the involvement of the father and the mother in parenting. In the study, it was found that a decrease in marital satisfaction predicted the emergence of competitive co-parenting and the lack of the father's involvement in parenting. Consistent with the findings, Block (2016) also found approximately the same thing. Relationship satisfaction felt by the father/husband become a predictor of co-parenting.

The previous studies confirmed that marital quality of the father and the mother form an important 
basis for establishing a good co-parenting alliance. For this reason, efforts to improve marital quality are inevitable in order to create good co-parenting. Factors that affect marital quality or marital satisfaction should be the father and the mother's concern in order to make their co-parenting work better. This was also confirmed by K. D. Pruett \& Pruett (2009) who asserted that co-parenting will function optimally if a healthy relationship exists between the parents, in this case, a healthy relationship between husband and wife. If drawn further on, it actually refers to the marital relationship between husband and wife.

Various studies have been conducted to determine the factors that affect the quality of marriage and marital satisfaction (i.e. Hyun \& Shin, 2010; Litzinger \& Gordon, 2005; Schneewind, 2002). Various studies have also consistently found that communication, conflict resolution, and joint leisure time have a positive relationship with marital satisfaction (Hill, 1988; Holman \& Jacquart, 1988; Orthner, 1975; Litzinger $\&$ Gordon, 2005). Therefore, efforts to improve the relationship of husband and wife through good quality of communication, constructive conflict resolution, and satisfying joint leisure time are necessary to build a good co-parenting alliance.

\section{Conflict Resolution}

K. D. Pruett \& Pruett (2009) provided several signs of conflicts that are not fully resolved, for example, the individuals become more argumentative and aggressive than usually, act passive aggressive, such as making the situation harder while acting cooperative, not talking much, and being cold and indifferent. In terms of parenting, unresolved conflict will make one spouse become unsupportive of their partner's decision or choice, or even extremely reject the discipline applied to children by blaming on it in front of the child. As a result, the child's personality development will not be carried out effectively.

In order that co-parenting can run optimally, is it essential for both father and mother to develop their ability in conflict resolution so that they can overcome the existing differences and find an acceptable solution for both of them, which will be implemented in their parenting practices. They have to build a constructive conflict resolution, not a destructive resolution. According to Olson, Olson-Sigg, and Larson (2008), there are several things that should be done in order to reach constructive resolution, including: a. Ongoing issues and problems are communicated clearly while old problems should not be brought up.

b. Both positive and negative feelings that arise should be expressed, not only the negative feelings.

c. Information should be delivered completely and honestly.

d. The discussion should focus on the problem not the person, and should not try to find a party to blame.

e. Perception orientation should focus on things in common rather than differences.

f. Relationships and discussions are based on trust, not suspicion.

\section{Communication}

In order to achieve conflict resolution, open and assertive communication, accompanied by affection is required (K. D. Pruett \& Pruett, 2009). Several types of communication that do not support the achievement of constructive conflict resolution are passive communication, aggressive communication, and passive-aggressive communication. On the contrary, the type of communication that is conducive to the achievement of constructive conflict resolution is assertive communication.

According to Olson et al. (2008), individuals that develop passive communication, do not honestly express their views, feelings, or desires. Such individuals usually are less concerned or surrender to their partner's view or decision. In the case of coparenting, this passive communication disables the father and the mother in being a mutually enriching team that builds the child's personality.

Unlike passive communication, individuals with aggressive communication voice their opinions vocally and impose their desires and needs, even if it violates other people's rights or hurt them (Olson et al., 2008). In co-parenting efforts, if the father and the mother have an aggressive communication style, they will absolutely develop negative feelings towards their parent and even blame the partner's views in front of the child. This condition will hinder the joint effort to foster and develop the child's entrepreneurial personality.

In passive-aggressive communication, individuals act as if they have sacrified their rights and desires, yet subtly convey anger and seek ways to take revenge at another time (Olson et al., 2008). In front of their partner, individuals will show support, but when the partner is not around, he/she will act ag- 
gressive. It is not impossible for this kind of individual to break their partner's argument in front of the child when the partner is not present. This will also hamper the co-parenting efforts in developing the child's entrepreneurial personality characteristics.

In assertive communication, individuals express their feelings, rights, and desires, but do not violate other people's rights. In other words, assertive is the midpoint of passive and aggressive. In this communication style, there is a dialogue between the father and the mother. In assertive communication, the ability to listen empathetically to the needs and views of the partner is needed. The purpose of this is to reach a solution acceptable to both parties. In the context of co-parenting, assertive communication between the father and the mother will create agreements regarding the personality characteristics they want to develop in the child and real ways that need to be done to achieve the goal. Both father and mother will be a team that supports each other in the efforts to achieve the desired personality characteristics in the child. This will create a very condusive environment for the attainment of the goals.

\section{Joint Leisure Time}

The positive communication will be more optimal if the father and the mother spend free time together. In co-parenting, joint leisure time allows the father and the mother to synchronize their vision and 'frequency.' Having joint leisure time will enable the father and the mother to communicate more comfortably, express their views, feelings, fears, and expectations related to the child. This is certainly needed to resolve conflicts regarding the child. With joint leisure time, the married couple can build togetherness, and bind themselves to each other closer, which results in the strengthening of their marriage stability (Hill, 1988; Reissman, Aron, \& Bergenet, 1993).

\section{Conclusion}

Efforts to develop entrepreneurial personality in children require co-parenting that focuses on the balance between care and challenge. Care will make the child feel safe, become braver to be him/herself, express ideas, be creative, and persist in working towards goals. Challenges will stimulate the child to continue to be creative, not stay in the status quo, be brave and ready to accept, manage, and even create changes. To optimize co-parenting, the father and the mother need to go back to the pillars of parenting, which are the strengthening of the marital relationship based on assertive communication, constructive conflict resolution, and the provision of effective joint leisure time.

\section{References}

Bandura, A. (1997). Self-efficacy: The exercise of control. New York: Freeman.

Block, J. (2016). Relationship satisfaction and coparenting over the transition to parenthood: Depression, division of labor, and child temperament as moderators (Unpublished Master's thesis). Retrieved from http://digitalcommons.od u.edu/cgi/viewcontent.cgi?article $=1019 \&$ context =psychology_etds

Bolton, B., \& Thompson, J. (2004). Entrepreneurs: Talent, temperament, technique (2nd ed.). Norfolk: Biddles Ltd.

Chell, E. (2008). The entrepreneurial personality: A social construction. Hove: Routledge.

Christopher, C., Umemura, T., Mann, T., Jacobvitz, D., \& Hazen, N. (2015). Marital quality over the transition to parenthood as a predictor of co-parenting. Journal of Child and Family Studies, 24 (12), 3636-3651.

Cordova, J. (2009). The marriage checkup: A scientific program for sustaining and strengthening marital health. Plymouth, UK: Jason Aronson.

Di Paula, A., \& Campbell, J. D. (2002). Self-esteem and persistence in the face of failure. Journal of Personality and Social Psychology, 83(3), 711724.

Feinberg, M. E. (2003). The internal structure and ecological context of co-parenting: A framework for research and intervention. Parenting: Science and Practice, 3(2), 95-131.

Hartini, N. (2011). Keluarga: Awal membangun karakter bangsa. In Y. Probowati, S. Handoyo, \& A. Matulessy (Eds.), Pendidikan karakter: Perspektif guru dan psikolog (pp. 69-82). Malang: Selaras.

Hill, M. S. (1988). Marital stability and spouses' shared time: A multidisciplinary hypothesis. Journal of Family Issues, 9(4), 427-451.

Hisrich, R. D., Peters, M. P., \& Shepherd, D. A. (2005). Entrepreneurship (6th ed.). Boston: Mc Graw-Hill.

Hisrich, R., Langan-Fox, J., \& Grant, S. (2007). Entrepreneurship research and practice: A call to ac- 
tion for psychology. American Psychologist, 62 (6), 575-589.

Holman, T. B., \& Jacquart, M. (1988). Leisureactivity patterns and marital satisfaction: A further test. Journal of Marriage and Family, 50(1), 69-77.

Hyun, S., \& Shin, H. (2010). Korean pastors and their wives' marital satisfaction and its predicting factors. Pastoral Psychology, 59(4), 495-512.

Janis, I. L. (Ed.). (1969). Personality: Dynamics, development, and assessment. New York: Harcourt, Brace \& World, Inc.

Katz, J. A. (2007). Education and training in entrepreneurship. In J. R. Baum, M. Frese, \& R. Baron (Eds.), The psychology of entrepreneurship (pp. 209-235). Mahwah, NJ: Lawrence Erlbaum Associates, Inc.

Küçük, S., Habaci, M., Göktürk, T., Ürker, A., \& Adiguzelli, F. (2012). Role of family, environment and education on the personality development. Middle-East Journal of Scientific Research, 12(8), 1078-1084.

Kurniawan, J. E., \& Setiawan, J. L. (2016). Pengembangan model dukungan sosial orang tua berbasis relasi pernikahan untuk meningkatkan entrepreneurial self-efficacy (Unpublished Final Report of Higher Education Superior Research Grant/Laporan Akhir Penelitian Unggulan PerguruanTinggi). Universitas Ciputra, Surabaya.

Litzinger, S., \& Gordon, K. C. (2005). Exploring relationships among communication, sexual satisfaction, and marital satisfaction. Journal of Sex \& Marital Therapy, 31(January), 409-424.

Maccoby, E. E., Depner, C. E., \& Mnookin, R. H. (1990). Co-parenting in the second year after divorce. Journal of Marriage and the Family, 52(1), 141-155.

McHale, J. P., \& Lindahl, K.M. (2011). Co-parenting: A conceptual and clinical examination of $f a-$ mily systems. Washington, DC: American Psychological Association Press.

McHale, J. P., Kuersten-Hogan, R., \& Rao, N. (2004). Growing points for co-parenting theory and research. Journal of Adult Development, 11(3), 221-234.

Morrill, M. I., Hines, D. A., Mahmood, S., \& Cordova, J. V. (2010). Pathways between marriage and parenting for wives and husbands: The role of coparenting. Family Process, 49(1), 59-74.

Morris, M. H. (1998). Entrepreneurial intensity: Sustainable advantages for individuals, organizations, and societies. Westport, Connecticut: $\mathrm{Qu}-$ orum Books.
Nwankwo, B. E., Obi, T. C., \& Agu, S. A. (2013). Relationship between self-esteem and achievement motivation among undergraduates in South Eastern Nigeria. IOSR Journal of Humanities and Social Science, 13(5), 102-106.

O'Leary, S. G., \& Vidair, H. B. (2005). Marital adjustment, child-rearing disagreements, and over reactive parenting: Predicting child behavior problems. Journal of Family Psychology, 19(2), 208216.

Olson, D., Olson-Sigg, A., \& Larson, P. J. (2008). The couple checkup. Nashville, Tennessee: Thomas Nelson.

Orthner, D. K. (1975). Leisure activity patterns and marital satisfaction over the marital career. Journal of Marriage and Family, 37(1), 91-102.

Owens, K. (1995). Raising your child's inner selfesteem. New York: Plenum Publishing Corporation.

Pruett, K. D., \& Pruett, M. K. (2009) Partnership parenting: How men and women parent differently-why it helps your kids and can strengthen your marriage. Cambridge: Da Capo Press.

Pudjibudojo, J. K. K. (2011). Anak dan pendidikan karakter. In Y. Probowati, S. Handoyo, \& A. Matulessy (Eds.), Pendidikan karakter: Perspektif guru dan psikolog (pp. 83-100). Malang: Selaras.

Rauch, A., \& Frese, M. (2007). Born to be an entrepreneur? Revisiting the personality approach to entrepreneurship. In J. R. Baum, M. Frese, \& R. Baron (Eds.), The psychology of entrepreneurship (pp. 209-235). Mahwah, NJ: Lawrence Erlbaum Associates, Inc.

Reissman, C., Aron, A., \& Bergen, M. R. (1993). Shared activities and marital satisfaction: Causal direction and self-expansion versus boredom. Journal of Social and Personal Relationships, 10(2), 243-254.

Saadat, M., Ghasemzadeh, A., Karami, S., \& Soleiman, M. (2012). Relationship between selfesteem and locus of control in Iranian university students. Procedia-Social and Behavioral Sciences, 31, 530-535.

Santrock, J. W. (2015). Life-span development (15th ed.). New York, NY: McGraw-Hill.

Scherer, R. F., \& Adams, J. S. (1989). Developing entrepreneurial behaviours: A social learning theory perspective. Journal of Organizational Change Management, 2(3), 16-27.

Schneewind, K. (2002). Relationship personality, conflict resolution, and marital satisfaction in the first 5 years of marriage. Family Relations, 51(1), 63-71. 
Setiawan, J. L. (2005). Building self-esteem in the early years. Psikologika Jurnal Pemikiran dan Penelitian Psikologi, X(20), 134-140.

Setiawan, J. L. (2008). Pembangunan bangsa melalui pembangunan karakter entrepreneurship: Peran psikologi, pendidikan dan masyarakat. Proceeding: Temu Ilmiah Nasional Ikatan Psikologi Perkembangan Indonesia, Menata Karakter Bangsa,
Bandung 28-29 Oktober 2008, (pp. 111-124).

Setiawan, J. L. (2011). Peran bimbingan konseling dalam pengembangan karakteristik entrepreneur mahasiswa. In Y. Probowati, S. Handoyo, \& A. Matulessy (Eds.), Pendidikan karakter: Perspektif guru dan psikolog (pp. 253-271). Malang: Selaras. World Economic Forum. (2016). The global competitiveness report. Geneva: World Economic Forum. 